\title{
Students' Perception On Virtual Group Of E-Learning In The Middle Of Pandemic Covid -19
}

\author{
Ratna Said \\ Prodi Pendidikan Guru Sekolah Dasar, Universitas Muhammadiyah Buton \\ Email; ratnasaidppsunj@gmail.com
}

\begin{abstract}
Abstrct. The research aims to describe students' perception on virtual group of e-learning in the middle of pandemic Covid-19. This research is a descriptive study with two types of research methods, namely library research and Google form questionnaire survey research. Result of the research shown that there was a positive perception of virtual group members through confidence $35,7 \%$, collaboration $60,7 \%$, accountability 57, $1 \%$ and encounter obstacle in virtual group 60, $7 \%$.
\end{abstract}

Key Words: e-learning, students 'perception, virtual group

\section{INTRODUCTION}

Education in Indonesia is now in a new phase, namely the education era 4.0 and will prepare to enter the education era 5.0. This era where the learning process is known as ICT (Information and Communications Technology). ICT in education system, where the teaching process uses digital technology. The implication of digital technology provides many conveniences, namely the emergence of various platforms such as WhatsApp, Zoom, Google classroom, Google meet, YouTube, WebEx, Loom and others to facilitate learning that cannot be done face-to-face, now can be done remotely with the capacity of participants who very much that is, it can reach hundreds of participants in the meeting. Not only that, we can also store very large data in Google drive or cloud. This is a facility provided by the application of digital technology.

In addition to convenience, of course, there are also weaknesses if you are not ready or unable to apply this digital technology. This brings us to a change in mindset and to a new challenge, namely readiness into implementation. Of course it will raise challenges for the implementation of educational programs in fulfilling access such as facilities, infrastructure and teaching staff, obstacles faced by students, especially Um Buton university students. Such as the availability of devices and data packages to access the internet. In the field of facilities and infrastructure, of course, everything has to be digital-based or start online processing. Likewise, educators must be able to adapt and take advantage of digital services in delivering learning materials called e-learning.

Not only that, education is currently facing tremendous challenges because it is being hit by the Covid-19 pandemic. The Covid-19 pandemic resulted in the Indonesian state implementing large-scale restrictions, physical distancing and social distancing so that it had a very negative impact in various sectors, especially education. Fortunately, the academic community is familiar with cyber technology or internet media so that obstacles in the field of education as a result of largescale restrictions involved social distancing and physical distancing can be overcome by implementing online learning by using learning application based on internet technology. From the description above, it raises the research title of the study to find out how the students' perception on the virtual group of e-learning in the middle of the COVID-19 pandemic.

\section{E-learning}

(Samir Abou El-Seoud et al., 2014) the term of e -learning is defined as any learning that involves using internet or intranet. Then the definition more generalized by indicating that it is anything delivered, enable, or mediated by electronic technology for explicit purpose of learning. (Ghirardini, 2011)E-learning can be defined as the use of computer and Internet 
technologies to deliver a broad array of solutions to enable learning and improve performance. (Al-Fraihat et al., 2020)Evaluating E-learning systems success: An empirical study e-learning, as a direct result of the integration of technology and education, has emerged as a powerful medium of learning particularly using Internet technologies. Furthermore Woon (2019) e-Learning is not only means online learning, virtual learning, distributed learning and networked or webbased learning, but also e-learning incorporates all educational activities that are carried out by individuals or groups working online or offline, and synchronously or asynchronously via networked or standalone computers, mobile and other electronic devices".

\section{Students' Perception}

Hoffman, Singh \& Prakash (2015) our perceptions of space-time and objects have been shaped by natural selection to hide the truth and guide adaptive behaviors. Perception is an adaptive interface. Furthermore, studies show that students' perception of e-learning in university education may be influenced by several variables. Keller and Cernerud (Popovoci \& Minoref, 2015) have identified variables such as age, gender, previous experience of computers, technology acceptance and individual learning styles as major predictive factors when discussing acceptance of technology by students. There are various theories of technology acceptance used to appreciate the perceptions of students.

\section{Virtual Grup}

Chinowsky \& Rojas (Falls, Bahhouth, Chuang, Bahhouth, 2014) "Virtual groups have been defined as students working together as a small group, executing simultaneous, collaborative work processes through electronic media without regard to geographic location".

They also stated five essential pillars for building an effective collaborative experience are described as follows: a) positive interdependence refers to the belief that each group member is dependent on the contribution of everybody else and that all members have a common goal attainable only by working together. When students clearly understand positive interdependence, they understand that each group member's efforts are required and indispensable for group success and each group member has a unique contribution to make to the joint effort. This is the most important and yet the most challenging to implement in teamwork learning; b). Promote interaction includes the exchanges among group members to help one another by sharing information, providing appropriate feedback on performance, showing trustworthiness, and facilitating members' efforts toward the accomplishment of goals. Johnson et al. (1991) named this component "Promotive face to face interaction" indicating that it is crucial to meet in person as a team for it to be effective, which makes it even more challenging in online courses; c) Individual accountability is closely related to the social motivation theory and refers to the awareness that each group member should be held accountable for his or her performance and learning; d) Group processing refers to all interactions and exchanges among group members which either facilitated or hindered the group's productivity and advancement toward the common goal; e) Social skills include the students' ability to interact smoothly with each other at the interpersonal and group level. To enhance all students' necessary communication competencies, instructors provide specific training and basic information at the beginning of the course, focusing on knowledge of basic netiquette rules. CFI (2015) a virtual team, also known as a geographically dispersed team or a remote team, is a group of people who interact through electronic communications. Members of a virtual team are usually located in different geographical regions. Since communication is not in-person, trust and good communication are crucial to the success of a virtual team. Project Manager (2020) a virtual team is a group of workers who communicate and work 
together using digital tools. While they can be located in the same physical space, virtual teams are often distributed, working remotely in different parts of the city, state or countryeven on the other side of the world

\section{RESEARCH METHODS}

This research is a descriptive study with two types of research methods, namely library research and Google form questionnaire survey research. The data collection methods chosen were primary and secondary data collection. Secondary data is data obtained in the form of online publications which are used as literature in the form of scientific journals. Primary data obtained in this study are divided into qualitative primary data and quantitative primary data. Qualitative primary data were obtained earlier when the research was conducting library research, while quantitative primary data were obtained based on surveys. The Google form questionnaire which is distributed to students was directed to found such issues: first, a screening which aims to filter out respondents who are Muhammadiyah University of Buton's students who used online applications during Covid-19. Second, general questions which were the main questions to answer research problems, how is the perception of Muhammadiyah University of Buton's students on learning English in the middle of the Covid -19 pandemic. Third, Respondent demographics which aim to find out more about the characteristics of respondents. The size and sampling method in this research by considering the target population that has the following criteria: a) Respondents used an internet application in online learning. b) Students of Muhammadiyah University of Buton which in virtual group. c) Respondents are decision makers. The sample chosen in this study were students who's fulfilled those criteria's and an online questionnaire.

Data analysis was carried out after the data obtained from the respondents were entered into the computer in the form of coding, then the data was obtained using IBM SPSS Statistics 26. The results of the SPSS output were then analysed. Descriptive Analysis is carried out at the initial stage of the data analysis process and becomes the basis for further analysis. The results of descriptive analysis calculations can be used to determine in general the patterns of answers given by respondents. The form of the calculation result is the Central tendency which describes the frequency of responses to the respondent's answers, such as the mean (average), mode (the most frequent value) and median (middle value) Variability measurement which explains how far the response is different, including the frequency distribution, range, and standard deviation.

\section{RESULTS AND DISCUSSION}

The data in this study are primary data taken from the research questionnaire that has been distributed via Google form to students. From Google form obtained 43 respondents. Respondents who met the criteria in this study were 27 respondents with characteristics of sex (gender), age (age) and media.

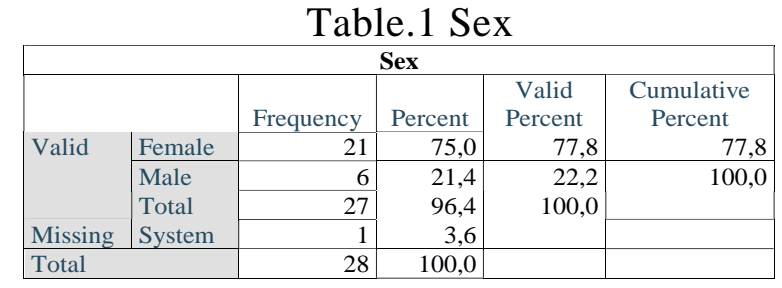

Based on the information in the table above, it can be seen about the gender of the respondent. The female gender was the most dominant in this study at $75.0 \%$ and male gender only $21.4 \%$.

\begin{tabular}{|c|c|c|c|c|c|}
\hline \multicolumn{6}{|c|}{ Age } \\
\hline & & Frequency & Percent & $\begin{array}{c}\text { Valid } \\
\text { Percent }\end{array}$ & $\begin{array}{c}\text { Cumulati } \\
\text { ve } \\
\text { Percent }\end{array}$ \\
\hline \multirow[t]{5}{*}{ Valid } & \begin{tabular}{|l|}
$19-23$ \\
\end{tabular} & 24 & 85,7 & 88,9 & 88,9 \\
\hline & $24-28$ & 1 & 3,6 & 3,7 & 92,6 \\
\hline & $29-33$ & 1 & 3,6 & 3,7 & 96,3 \\
\hline & 34-38 & 1 & 3,6 & 3,7 & 100,0 \\
\hline & Total & 27 & 96,4 & 100,0 & \\
\hline Missing & System & 1 & 3,6 & & \\
\hline \multicolumn{2}{|l|}{ Total } & 28 & 100,0 & & \\
\hline
\end{tabular}

Based on the information in the table above, it showed that the age range of respondents 1923 who became the sample in this study was the most with $85,7 \%$.

Table.3 Virtual Group Application Media 
Terakreditasi Peringkat 5 (No. SK: 85/M/KPT/2020)

\begin{tabular}{|c|c|c|c|c|c|}
\hline \multicolumn{6}{|c|}{ Virtual Group Application Media } \\
\hline & & Frequency & Percent & $\begin{array}{c}\text { Valid } \\
\text { Percent }\end{array}$ & $\begin{array}{l}\text { Cumula } \\
\text { tive } \\
\text { Percent }\end{array}$ \\
\hline \multirow[t]{3}{*}{ Valid } & WhatsApp & 26 & 92,9 & 96,3 & 96,3 \\
\hline & $\begin{array}{l}\text { Zoom } \\
\text { Meeting }\end{array}$ & 1 & 3,6 & 3,7 & 100,0 \\
\hline & Total & 27 & 96,4 & 100,0 & \\
\hline Missing & System & 1 & 3,6 & & \\
\hline \multicolumn{2}{|l|}{ Total } & 28 & 100,0 & & \\
\hline
\end{tabular}

The data shown varieties of platform or media which is using in virtual group such as WhatsApp, Zoom meeting, the most of participant prefer to use was WhatsApps media with $92.9 \%$. In the case of the simple using compare to the other platform.

Table. 4 Confidence in Virtual Group

Do you have confidence that every member of the virtual group contributes well

\begin{tabular}{|c|c|c|c|c|c|}
\hline & & Frequency & Percent & $\begin{array}{c}\text { Valid } \\
\text { Percent }\end{array}$ & $\begin{array}{c}\text { Cumulative } \\
\text { Percent }\end{array}$ \\
\hline \multirow[t]{4}{*}{ Valid } & Yes & 10 & 35,7 & 37,0 & 37,0 \\
\hline & May Be & 10 & 35,7 & 37,0 & 74,1 \\
\hline & No & 7 & 25,0 & 25,9 & 100,0 \\
\hline & Total & 27 & 96,4 & 100,0 & \\
\hline Missing & System & 1 & 3,6 & & \\
\hline \multicolumn{2}{|l|}{ Total } & 28 & 100,0 & & \\
\hline
\end{tabular}

Based on the information in the table above, it described that the members of virtual group who were believing in their own confidence that each members has given good contribution or participated well and members with doubt that members shared any information and gave feedback in purpose of personal and group development shown in equal rate was $35,7 \%$. And $10 \%$ who did not give any trust in virtual group, they were prefer to face to face group.

Table. 5 Collaboration in Virtual Groups

\begin{tabular}{|c|c|c|c|c|c|}
\hline \multicolumn{6}{|c|}{$\begin{array}{l}\text { Do virtual group members help each other by sharing information, } \\
\text { providing appropriate feedback on performance, demonstrating trust, and } \\
\text { facilitating members' efforts to achieve goals? }\end{array}$} \\
\hline \multirow{5}{*}{ Valid } & & Frequency & Percent & $\begin{array}{l}\text { Valid } \\
\text { Percent }\end{array}$ & $\begin{array}{l}\text { Cumulative } \\
\text { Percent }\end{array}$ \\
\hline & Yes & 17 & 60,7 & 63,0 & 63,0 \\
\hline & May Be & 8 & 28,6 & 29,6 & 92,6 \\
\hline & \begin{tabular}{|l|} 
No \\
\end{tabular} & 2 & 7,1 & 7,4 & \multirow[t]{2}{*}{100,0} \\
\hline & Total & 27 & 96,4 & 100,0 & \\
\hline $\begin{array}{l}\text { Missin } \\
\mathrm{g}\end{array}$ & System & 1 & 3,6 & & \\
\hline Total & & 28 & 100,0 & & \\
\hline
\end{tabular}

Based on the information in the table above, it described that the members of virtual group helped each other by sharing information, providing appropriate feedback on performance, demonstrating trust, and facilitating members' efforts to achieve goals, was $60,7 \% .28,6 \%$ in doubt and 7, $1 \%$ who thought there was not good participation.

Table.6 Accountability in Virtual Groups

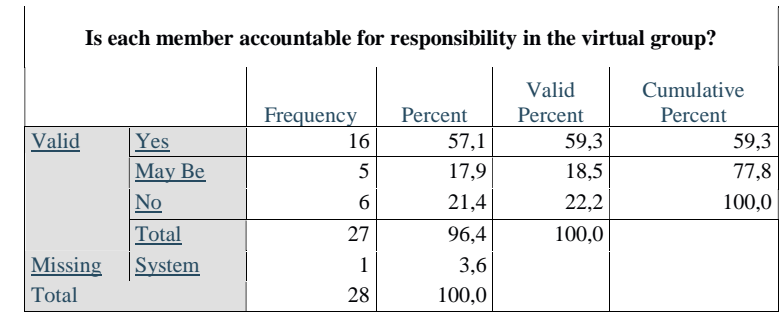

Based on the information in the table above, it described that the members of virtual group who were believing that each member was accountable for responsibility in the virtual group was $57,1 \%$. With doubt was $17,9 \%$ and $21,4 \%$ who did not give any trust in virtual group, they were prefer to face to face group.

Table.7 Barriers in Virtual Group

\begin{tabular}{|c|c|c|c|c|c|}
\hline \multicolumn{6}{|c|}{ Do you encounter obstacles in interacting in virtual groups? } \\
\hline & & Frequency & Percent & Valid Percent & $\begin{array}{l}\text { Cumulati } \\
\text { ve } \\
\text { Percent }\end{array}$ \\
\hline \multirow[t]{4}{*}{ Valid } & Yes & 17 & 60,7 & 63,0 & 63,0 \\
\hline & May Be & 5 & 17,9 & 18,5 & 81,5 \\
\hline & No & 5 & 17,9 & 18,5 & 100,0 \\
\hline & Total & 27 & 96,4 & 100,0 & \\
\hline Missing & System & 1 & 3,6 & & \\
\hline \multicolumn{2}{|l|}{ Total } & 28 & 100,0 & & \\
\hline
\end{tabular}

Based on the information in the table above, it described that the members of virtual group who were believing in their encounter obstacles in interacting were higher was 60 , $7 \%$. And 17, $9 \%$ who were in doubt and did not give any trust in virtual group, they were prefer to face to face group.

\section{CONCLUSION}

The results of this study can be concluded that there was a positive perception of virtual group members through confidence $35,7 \%$, collaboration $60,7 \%$, accountability $57,1 \%$ and encounter obstacle in virtual group $60,7 \%$.

\section{SUGGESTION}

There is a need for further research on student trust in virtual groups in learning

\section{THANKS - NOTE}

Thanks to Muhammadiyah Buton University, Teacher Training and Education Faculty, Elementary School Study Program and all parties involved in this research.

\section{BIBLIOGRAPHY}

Al-Fraihat, D., Joy, M., Masa'deh, R., \& Sinclair, J. (2020). Evaluating E-learning 
systems success: An empirical study. Computers in Human Behavior. https://doi.org/10.1016/j.chb.2019.08.004 CFI. (2015). Virtual Team.[Online]. Available:

https://corporatefinanceinstitute.com/reso urces/knowledge/other/virtual-team/

Ghirardini, B. (2011). E-learning methodologies: A guide for designing and developing e-learning courses. Food and Agriculture Organization of the United Nations (FAO). https://doi.org/I2516E/1/11.11

Hoffman, Singh \& Prakash. 2015. Psychonomic Bulletin and Review. 14801506. DOI: $10.3758 / \mathrm{s} 13423-015-0890-8$

Popovici, Anca \& Cosmina Mironov. 2015. Students' perception on using eLearning technologies. Procedia - Social and Behavioral Sciences Journal.1514 - 1519

Project Manager. 2020. What Is a Virtual Team? Definition \& Examples. [Online]. Available:

https://www.projectmanager.com/blog/w hat-is-a-virtual-team

Rina Falls, Victor Bahhouth, Chiuchu Melody Chuang, and Jocelyne Bahhouth.2014. Factors Influencing Students' Perceptions of Online Teamwork. Sage Open Journal. DOI: 10.1177/2158244014525415

Samir Abou El-Seoud, M., Taj-Eddin, I. A. T. F., Seddiek, N., El-Khouly, M. M., \& Nosseir, A. (2014). E-learning and students' motivation: A research study on the effect of e-learning on higher education. International Journal of Emerging Technologies in Learning, 9(4), 20-26. https://doi.org/10.3991/ijet.v9i4.3465

Woon, You Huay.2019. Students' Perception about Learning using MOOC. International Journal of Emerging Technologies in Learning (iJET) .14(18) 203 